\title{
Physical Evaluation on the Students of Jiangxi Normal University Affiliated Middle School
}

\author{
Zu-Hua Xie ${ }^{1}$, Hui-Hui Li ${ }^{2}$, Shao-Xuan Chen ${ }^{1}$, Teng-Fei Yao ${ }^{1}$, Zhao-Lian Yuan ${ }^{1}$ \\ ${ }^{1}$ Jiangxi Normal University, Nanchang, China \\ ${ }^{2}$ Zhongnan University of Economics and Law, Wuhan, China
}

\begin{abstract}
To evaluate the fitness of the students in Jiangxi Normal University Affiliated Middle School, the indices of the body shape and the body function were measured in this paper. The results show that the body shape of these students is normal, but the physical functions of them are not so good. For example, the strength of the legs are not enough for the male students, a high proportion of the male students failed in the vital capacity test, the strength of upper limb of the male students is too weak, the aerobic endurance capacity is relatively poor. For the female students, their strength is good, only a small number of them failed in the strength tests, but their vital capacity is too small. Therefore, aerobic endurance exercises are needed for both the girls and the boys.
\end{abstract}

Keywords-Education school; Physical tests; Senior high school; Health status

\section{INTRODUCTION}

With the rapid development of science and society, the national health status has been an unprecedented attention [1]. Middle school students are the main force of the future construction of the motherland, which is the backbone of the great rejuvenation of the Chinese nation on the practice of those who practice [2]. Since the reform and opening up, with the rapid development of China's economy, the gradual improvement of living standards, the physical health of students has been greatly improved, but also accompanied by another problem, that students show physical health declining trend. In order to strengthen the monitoring of students 'physical health, to strengthen the school sports work, to protect students' ability to develop, improve their physical fitness, cultivate the habit of physical exercise, improve physical and physical fitness and improve the physical health level [3]. This study attempts to investigate the current situation of physical fitness test of high school sophomore secondary school students in Jiangxi Normal University, and reveals the problems of physical health of high school sophomore students in Yuhua School and puts forward the corresponding optimization measures.

\section{SUBJECTS AND METHODS}

\section{A. Subjects}

Using the original data of secondary school high school first grade and high school sophomore sports test, the students of these two grades as the test object, including high school first grade boys 70 people, girls 80 people; high school sophomore boys 111 people, Female 92 people, a total of 353 people.

\section{B. Methods}

According to the contents and purpose of the study, access to the collection of the State Ministry of Education, the General Administration of Sport issued the relevant documents and Nanchang issued a variety of documents, and through access to China Knowledge Network, Wei Pu and other databases access to physical health test related literature and journals And related sports theory books, etc., for the study of the paper provides a lot of theoretical knowledge based on the reserves of knowledge. Perform the field test on the grade of the study and record the real experimental data. Men test items: height, weight, standing long jump, seat flexion, pull up, 1000m; women test items: height, weight, standing long jump, seat flexion, 1min sit-ups and $800 \mathrm{~m}$. Finally, SPSS 17.0 and EXCEL 2003 were used to classify the data.

\section{RESULTS AND DISCUSSION}

\section{A. Boys and girls body shape of the situation}

The results of the students' height, weight and vital capacity test are shown in Table I II.

TABLE I. MALE BODY SHAPE STATISTICS

\begin{tabular}{|c|c|c|c|}
\hline Grade & $\begin{array}{c}\text { Height } \\
\text { mean }\end{array}$ & $\begin{array}{c}\text { weight } \\
\text { mean }\end{array}$ & $\begin{array}{c}\text { Vital capacity } \\
\text { mean }\end{array}$ \\
\hline First & $173 \mathrm{~cm}$ & $67 \mathrm{~kg}$ & $3718 \mathrm{ml}$ \\
\hline Second & $173.5 \mathrm{~cm}$ & $69 \mathrm{~kg}$ & $4213 \mathrm{ml}$ \\
\hline
\end{tabular}

TABLE II. FEMALE BODY SHAPE STATISTICS

\begin{tabular}{|c|c|c|c|}
\hline Grade & $\begin{array}{c}\text { Height } \\
\text { (mean) }\end{array}$ & $\begin{array}{c}\text { Weight } \\
\text { (mean) }\end{array}$ & $\begin{array}{c}\text { Vital capacity } \\
\text { (mean) }\end{array}$ \\
\hline First Grade & $161.5 \mathrm{~cm}$ & $54.3 \mathrm{~kg}$ & $2486 \mathrm{ml}$ \\
\hline Second Grade & $162.2 \mathrm{~cm}$ & $54 \mathrm{~kg}$ & $2850 \mathrm{ml}$ \\
\hline
\end{tabular}




\section{B. Test results and analysis of student body form}

TABLE III. MALE BMI SCORE STATISTICS

\begin{tabular}{|c|c|c|c|c|}
\hline \multirow{2}{*}{ Body type } & \multicolumn{2}{|c|}{ First Grade BMI $\left(\mathrm{kg} / \mathrm{m}^{2}\right)$} & \multicolumn{2}{|c|}{$\begin{array}{c}\text { Second Grade } \\
\text { BMI }\left(\mathbf{k g} / \mathrm{m}^{2}\right)\end{array}$} \\
\cline { 2 - 5 } & $(\boldsymbol{N})$ & $(\boldsymbol{\%})$ & $(\boldsymbol{N})$ & $(\%)$ \\
\hline Normal & 38 & 54.2 & 69 & 62.2 \\
\hline Low weight & 3 & 4.3 & 6 & 5.4 \\
\hline Overweight & 16 & 22.9 & 15 & 13.5 \\
\hline Obesity & 13 & 18.6 & 21 & 18.9 \\
\hline
\end{tabular}

By table III shows that $54.2 \%$ of all the boys in the high grade students normal body mass index (bmi), only $4.3 \%$ of the students of low weight, main problems of overweight and obesity were $22.9 \%$ and $18.6 \%$, respectively. The two boys are overweight and obesity is given priority to but smaller than the proportion of high points, significantly higher, normal proportion $62.2 \%$ overall.

TABLE IV. FEMALE BMI SCORE STATISTICS

\begin{tabular}{|c|c|c|c|c|}
\hline \multirow{2}{*}{ Body type } & \multicolumn{2}{|c|}{ First Grade BMI $\left(\mathrm{kg} / \mathrm{m}^{2}\right)$} & \multicolumn{2}{|c|}{$\begin{array}{c}\text { Second Grade } \\
\text { BMI }\left(\mathrm{kg} / \mathrm{m}^{2}\right)\end{array}$} \\
\cline { 2 - 5 } & $(\boldsymbol{N})$ & $(\%)$ & $(N)$ & $(\%)$ \\
\hline Normal & 60 & 75 & 70 & 76.1 \\
\hline Low weight & 1 & 1.2 & 7 & 7.6 \\
\hline Overweight & 13 & 16.3 & 10 & 10.9 \\
\hline Obesity & 6 & 7.5 & 5 & 5.4 \\
\hline
\end{tabular}

From the table IV shows that only $1.2 \%$ of the first year girls are low weight, normal weight accounted for $75 \%$ overweight and obesity significantly less than boys were $16.3 \%$ and $7.5 \%$ respectively. High school sophomore girls low body weight slightly slightly accounted for $7.6 \%$, normal weight accounted for $76.1 \%$ overweight and obesity, a higher proportion of girls were $10.9 \%$ and $5.4 \%$, the overall situation is basically normal.

\section{Test results and analysis of students' physical}

TABLE V. MALE STANDING LONG JUMP AND LUNG VOLUME SCORE STATISTICS

\begin{tabular}{|c|c|c|c|c|c|c|c|c|}
\hline \multirow{3}{*}{ Score } & \multicolumn{4}{|c|}{ First Grade } & \multicolumn{4}{|c|}{ Second Grade } \\
\cline { 2 - 10 } & \multicolumn{2}{|c|}{ Broad jump } & \multicolumn{2}{|c|}{ Vital capacity } & \multicolumn{2}{|c|}{ Broad jump } & \multicolumn{2}{|c|}{ Vital capacity } \\
\cline { 2 - 9 } & $(\mathrm{N})$ & $(\%)$ & $(\mathrm{N})$ & $(\%)$ & $(\mathrm{N})$ & $(\%)$ & $(\mathrm{N})$ & $(\%)$ \\
\hline Excellent & 7 & 10 & 18 & 25.7 & 7 & 6.3 & 46 & 41.4 \\
\hline Good & 13 & 18.6 & 18 & 25.7 & 23 & 20.7 & 21 & 18.9 \\
\hline Pass & 43 & 61.4 & 24 & 34.3 & 69 & 62.2 & 35 & 31.5 \\
\hline Failed & 7 & 10 & 10 & 14.3 & 12 & 10.8 & 9 & 8.2 \\
\hline
\end{tabular}

According to the table $\mathrm{V}$ shows that the first year of junior high school students long jump only $10 \%$ of the students fail another $90 \%$ of the students in $61.4 \%$ of the students in the pass and good students only $28.6 \%$, sophomore boys set long jump only $10.8 \%$ Of the classmates failed, and another $89.4 \%$ in $62.2 \%$ of the students in the good and good students accounted for $27 \%$. That Yuhua school high school sophomore grade students need to strengthen their lower limb strength exercise. $14.3 \%$ of the students with a higher lung capacity were eligible for another $85.7 \%$ of the students who were eligible for a higher grade than those in the sophomore year. The odds were higher than those of the higher grades and $41.4 \%$ were excellent. Overall, the students need to strengthen the leg strength of a little exercise, the proportion of the number of lungs fail to pass a little more.

TABLE VI. FEMALE STANDING LONG JUMP AND LUNG VOLUME SCORE STATISTICS

\begin{tabular}{|c|c|c|c|c|c|c|c|c|}
\hline \multirow{2}{*}{ score } & \multicolumn{4}{|c|}{ First Grade } & \multicolumn{4}{c|}{ Second Grade } \\
\cline { 2 - 9 } & \multicolumn{2}{|c|}{ Broad jump } & \multicolumn{2}{|c|}{ Vital capacity } & \multicolumn{2}{c|}{ Broad jump } & \multicolumn{2}{|c|}{ Vital capacity } \\
\cline { 2 - 9 } & $(\mathrm{N})$ & $(\%)$ & $(\mathrm{N})$ & $(\%)$ & $(\mathrm{N})$ & $(\%)$ & $(\mathrm{N})$ & $(\%)$ \\
\hline Excellent & 9 & 11.3 & 15 & 18.8 & 10 & 10.9 & 35 & 38 \\
\hline Good & 32 & 40 & 9 & 11.2 & 29 & 31.5 & 12 & 14 \\
\hline Pass & 37 & 48.2 & 43 & 53.8 & 51 & 55.4 & 34 & 37 \\
\hline Failed & 2 & 2.5 & 13 & 16.2 & 2 & 2.2 & 10 & 11 \\
\hline
\end{tabular}

From the table VI shows that the two grades of girls lower limb strength better, only the first grade only $2.5 \%$ of students fail, sophomore $2.2 \%$ of students fail; and high first grade girls lung capacity is not very good, $16.2 \%$ Pass, 53.8 pass only $30 \%$ of the students in the good range of good, sophomore girls a little better $11 \%$ of students fail, $27 \%$ of the students passing, $52 \%$ of the students in good or above, the overall leg strength is normal, vital capacity normal.

TABLE VII. MALE PULl UP SCORE STATISTICS

\begin{tabular}{|c|c|c|c|c|}
\hline \multirow{2}{*}{ score } & \multicolumn{2}{|c|}{ First Grade Pull up } & \multicolumn{2}{c|}{ Second Grade Pull up } \\
\cline { 2 - 5 } & $(\boldsymbol{N})$ & $(\boldsymbol{\%})$ & $(\boldsymbol{N})$ & $(\boldsymbol{\%})$ \\
\hline Excellent & 2 & 2.9 & 0 & 0 \\
\hline Good & 2 & 2.9 & 1 & 0.9 \\
\hline Pass & 1 & 1.4 & 18 & 16.2 \\
\hline Failed & 65 & 92.8 & 92 & 82.9 \\
\hline
\end{tabular}

According to the table VII, $92.8 \%$ of the students of the first grade were unqualified, $1.4 \%$ of the students were only $5.8 \%$ of the students were good; $82.9 \%$ of the sophomore boys failed, $16.2 \%$ of the students passed, $0.9 \%$ Good student is not good. Indicating that Yuhua school high school sophomore strength of the upper body is very weak, need to strengthen.

TABLE VIII. FEMALE 1MIN SIT-UPS SCORE STATISTICS

\begin{tabular}{|c|c|c|c|c|}
\hline \multirow{2}{*}{ Score } & \multicolumn{2}{|c|}{ First Grade 1min Sit- } & \multicolumn{2}{c|}{$\begin{array}{c}\text { Second Grade 1min } \\
\text { Sit-ups }\end{array}$} \\
\cline { 2 - 5 } & $(\boldsymbol{N})$ & $(\boldsymbol{\%})$ & $(\boldsymbol{N})$ & $(\boldsymbol{\%})$ \\
\hline Excellent & 17 & 21.2 & 11 & 12 \\
\hline Good & 12 & 15 & 20 & 21.7 \\
\hline Pass & 47 & 58.8 & 56 & 60.9 \\
\hline Failed & 4 & 5 & 5 & 5.4 \\
\hline
\end{tabular}

According to the table VIII, only $5 \%$ of the girls in the first year of the girls fail, $58.8 \%$ of the students pass $36.2 \%$ of the students in the good; high sophomore only $5.4 \%$ of the students fail, $60.9 \%$ of the students pass, $33.6 \%$ The students are above 
the good. This shows that high school sophomore girls waist strength as a whole good.

TABLE IX. MALE SCORES OF 1000M AND 50M

\begin{tabular}{|c|c|c|c|c|c|c|c|c|}
\hline \multirow{3}{*}{ score } & \multicolumn{4}{|c|}{ First Grade } & \multicolumn{4}{|c|}{ Second Grade } \\
\cline { 2 - 9 } & \multicolumn{2}{|c|}{$\mathbf{1 0 0 0 \boldsymbol { m }}$} & \multicolumn{2}{|c|}{$\mathbf{5 0 \boldsymbol { m }}$} & \multicolumn{2}{|c|}{$\mathbf{1 0 0 0} \boldsymbol{m}$} & \multicolumn{2}{|c|}{$\mathbf{5 0 \boldsymbol { m }}$} \\
\cline { 2 - 9 } & $(\mathrm{N})$ & $(\%)$ & $(\mathrm{N})$ & $(\%)$ & $(\mathrm{N})$ & $(\%)$ & $(\mathrm{N})$ & $(\%)$ \\
\hline Excellent & 3 & 4.3 & 16 & 22.9 & 0 & 0 & 44 & 39.6 \\
\hline Good & 5 & 7.1 & 5 & 7.1 & 1 & 0.9 & 14 & 12.6 \\
\hline Pass & 34 & 48.6 & 47 & 67.1 & 36 & 32.4 & 53 & 47.8 \\
\hline Failed & 28 & 40 & 2 & 2.9 & 74 & 66.7 & 0 & 0 \\
\hline
\end{tabular}

From the table IX shows that the $100 \mathrm{~m}$ project in a high of $40 \%$ of the students fail $48.6 \%$ of the students were better than $11.4 \%$ of the students; sophomore is still almost $66.7 \%$ of the students fail, $32.4 \%$ of the students pass, good For $0.9 \%$ excellent no. This shows that the overall quality of male endurance poor. For the $50 \mathrm{~m}$ sprint, the overall better, only the first grade only $2.9 \%$ of the students fail, $67.1 \%$ of the students pass, good $7.1 \%$, excellent $22.9 \%$; high sophomore overall higher than the first grade, no failed students , $47.8 \%$ of the students pass, $12.6 \%$ of the students are good, $39.6 \%$ of the students are excellent.

TABLE $X$. FEMALE SCORES OF 800M AND 50M

\begin{tabular}{|c|c|c|c|c|c|c|c|c|}
\hline \multirow{3}{*}{ score } & \multicolumn{4}{|c|}{ First Grade } & \multicolumn{4}{c|}{ Second Grade } \\
\cline { 2 - 10 } & \multicolumn{2}{|c|}{$\mathbf{0 0 0 \boldsymbol { m }}$} & \multicolumn{2}{|c|}{$5 \mathbf{m}$} & \multicolumn{2}{|c|}{$\mathbf{0 0 0} \boldsymbol{m}$} & \multicolumn{2}{|c|}{$\mathbf{5 0 m}$} \\
\cline { 2 - 10 } & $(\mathrm{N})$ & $(\%)$ & $(\mathrm{N})$ & $(\%)$ & $(\mathrm{N})$ & $(\%)$ & $(\mathrm{N})$ & $(\%)$ \\
\hline Excellent & 1 & 1.3 & 2 & 2.5 & 1 & 1.1 & 2 & 2.2 \\
\hline Good & 5 & 6.2 & 12 & 15 & 2 & 2.2 & 18 & 19.6 \\
\hline Pass & 50 & 62.5 & 62 & 77.5 & 19 & 20.7 & 67 & 72.8 \\
\hline Failed & 24 & 30 & 4 & 5 & 70 & 76 & 5 & 5.4 \\
\hline
\end{tabular}

From the table $\mathrm{X}$ shows that the first grade girls $800 \mathrm{~m}$ project $30 \%$ of the students fail, $62.5 \%$ of the students pass, good enough only $7.5 \%$; sophomore girls higher than the poor one of the $76 \%$ of the students do not Pass, $20.7 \%$ of the students pass, good and good students only 3.3\%, indicating high school sophomore girls overall tolerance deviation. $50 \mathrm{~m}$ sprint project, high one failed $5 \%, 77.5 \%$ pass, good were $2.5 \%$, $15 \%$; sophomore grade failed students accounted for $5.4 \%$, 72.8 pass, $19.6 \%$ good, excellent $2.2 \%$.

\section{An Analysis for the Reasons of Affecting Students' Physical Health}

- Yuhua school due to the lack of space, students a little lack of teacher guidance, coupled with the school enrollment, school facilities and per capita use of the area has been unable to meet the needs of students, only a basketball court and volleyball field add up to more than 2000 square meters, The equipment is only seven basketball, more than 20 volleyball, badminton 10 , the other is very few, so that most of the students for the enthusiasm of sports gradually fade until they do not want to participate in physical exercise; In addition, some sports on Venues rely on a higher degree, such as badminton, volleyball and other projects, these site factors on the student exercise also had a certain impact. In addition to the extracurricular physical exercise, even in the physical education class also showed lack of equipment, sometimes a class of three to four classes in the same playground, seriously affect the students' physical exercise, but also prone to accidents. So the students in addition to a particular sport is very interested in the students basically little physical exercise.

- The factors that affect students' physical exercise are the motive of sports, which is the psychological motivation of students to transform sports desire into sports behavior [4]. It is the source of students' motivation for sports activities to be an important factor influencing students' participation in sports activities [5]. For the age of the students in terms of physical training for the motives: physical fitness, enhance physical fitness, hobbies, entertainment and create a perfect body-based, girls are: weight loss, bodybuilding, shaping, enhance physical fitness, Keep fit and relax the brain, adjust your mood. The purpose of men and women are different, this result also with men and women of the physical and psychological differences have a very close relationship. Boys to participate in physical exercise The main purpose is to be able to effectively exercise the body to enhance physical fitness and there is a certain degree of entertainment and competitiveness to meet the male students of the strong sense of victory, and girls are mainly to lose weight to make their own More beautiful and more confident in life Another is to face the pressure of learning to relax under the mood, boys like to vent in the exercise and release of learning and life brought about by the depression and experience the fun of the sport, girls More attention to the beauty of the body. It seems that, in addition to a small number of students lacking motivation for physical exercise, other students are more motivated to participate in physical exercise and are able to recognize that exercise is an important part of physical exercise. Followed by shaping the size and entertainment pastime that shows that students participate in physical exercise relative to the students do not want to participate in the starting point is better and more active.

- Students will be able to spend their spare time on the Internet chat or games, review the learning content and complete the learning tasks, film entertainment, play, chess and so on only a few love sports of the students will carry out some sports.

- With the development of national fitness, the atmosphere of social physical exercise is also growing, people also began to face the value of physical exercise, family sports is also a factor affecting the physical exercise of students, the vast majority of parents still pay more attention to Support children often participate in physical exercise, but there are some parents that students are mainly academic and other are secondary, while ignoring the physical exercise of cultural schools have a certain role in promoting the efficiency of learning. 


\section{CONCLUSIONS AND RECOMMENDATIONS}

\section{A. Conclusions}

This study is to conduct a statistical survey on the physical health of high school students in Yuhua School affiliated to Jiangxi Normal University. The basic test data are obtained from body shape, physiological function and athletic quality, and the physical health status of high school students in Yuhua School is grasped. Provide a certain reference data to the future of physical education, as well as in the future selection of sports materials have a certain basis for this data from the source of statistics and I in September 2016 to November in Yuhua school practice to help the school teacher to complete. With the absolute authenticity and the comprehensiveness of the data, this comprehensive data statistics reflect the longitudinal trend of the physical education of school students, so as to make corresponding countermeasures. Statistics from the data point of view, the school students basically normal body shape, the boy's leg strength has a little lack in lung capacity less than the proportion of a little more, upper limb strength is too weak need to strengthen the exercise, aerobic endurance capacity is relatively poor, The Girls who have the normal speed have a good overall strength of the legs, only a small number of girls fail, the proportion of lung capacity is not a little more than the number of waist and abdomen muscle strength, aerobic endurance capacity need to strengthen the exercise, the speed is basically on the grid line.

\section{B. Recommendations}

Schools should strengthen the management of sports work and attach importance to the status of sports in the school, the teaching of students to "health first" guiding ideology teaching guidance, so that students can face the value of sports and its role, so as to stimulate students to sports The motive of the movement, the students develop the habit of physical exercise, to master some of them as a citizen should learn the skills and sports knowledge, lay the foundation for lifelong sports.

The school should be able to carry out the transformation of the corresponding equipment to explore a variety of sports equipment functions, as far as possible the development of all the value of the use of equipment, but also according to the needs of students on the site equipment to expand accordingly to meet the needs of students exercise.

Actively implement one hour of physical exercise every day, through the development of a variety of extracurricular sports activities, so that students get better exercise, and exercise every day for one hour included in the teaching plan, and thus more effective implementation.

The school can also give students a step on the impact of students on the physical exercise of the students, so that parents are aware that not only learning, physical exercise is also very important for children, so that the two sides to exert influence on students to promote their sports Exercise, improve health, develop the habit of physical exercise.

\section{ACKNOWLEDGMENT}

This work was supported by the Open Project Program of Key Lab of Training, Monitoring and Intervention of Aquatic Sports of General Administration of Sport of China, Jiangxi Normal University (NO. 201604).

\section{REFERENCES}

[1] Y.H.Zhang, L.R.Hou, Y.Y.Ju. Analysis on Physical Condition of Middle School Students in Sichuan Province [J]. Sichuan Sport Science, 2011, (02): 100-104. (In Chinese)

[2] C.Y.Hao.Study and Analysis of Physical Quality of Senior High School Students in Our University [J]. Weekly, 2015, (05): 226. (In Chinese)

[3] W.Li.Existing Problems and Solutions of "High School Physical Education Textbook" [J]. Acta Metallurgica Sinica, 2003, (03): 63-65. (In Chinese)

[4] K.C.Xu,J.Q.Li.Study on the Teaching Problems of P.E. Health Curriculum in High School in the New Period [J]. Journal of Beijing Sport University, 2004, (08): 1091-1093. (In Chinese)

[5] G.Ji,L.Z.Hou.Study on the Problems of Implementing Students' Physical Health Standard in Secondary Schools [J]. Journal of Beijing Sport University, 2006, (02): 253-255. (In Chinese) 